\title{
Irrigation Water Quality Assessment of Chitra River, Southwest Bangladesh
}

\author{
Rumpa Kundu, Mosummath Hosna Ara* \\ Chemistry Discipline, Khulna University, Khulna, Bangladesh \\ Email: rumpakundu@ku.ac.bd, ^hosnaara1@gmail.com
}

How to cite this paper: Kundu, R., \& Ara, M. H. (2019). Irrigation Water Quality Assessment of Chitra River, Southwest Bangladesh. Journal of Geoscience and Environment Protection, 7, 175-191.

https://doi.org/10.4236/gep.2019.74011

Received: February 27, 2019

Accepted: April 21, 2019

Published: April 24, 2019

Copyright $\odot 2019$ by author(s) and Scientific Research Publishing Inc. This work is licensed under the Creative Commons Attribution International License (CC BY 4.0).

http://creativecommons.org/licenses/by/4.0/ (c) (i) Open Access

\begin{abstract}
Narail Sadar Upazilla is a major agricultural productive region of Narail District, Bangladesh. The crop production here significantly depends on the Chitra River water for irrigation. The present study was undertaken with an aim to evaluate the usability of this river water for irrigation purpose during pre-monsoon, monsoon and post-monsoon. Sampling was conducted three times in each season both in high tide and low tide. The collected samples were analyzed for some physicochemical parameters including $\mathrm{pH}$, electrical conductivity (EC), total dissolved solid (TDS), major cations $\left(\mathrm{Na}^{+}, \mathrm{K}^{+}, \mathrm{Ca}^{2+}\right.$ and $\left.\mathrm{Mg}^{2+}\right)$ and major anions $\left(\mathrm{HCO}_{3}^{-}, \mathrm{PO}_{4}^{3-}, \mathrm{SO}_{4}^{2-}, \mathrm{Cl}^{-}\right.$and $\left.\mathrm{NO}_{3}^{-}\right)$. The calculated chemical indices' values for the collected water samples during pre-monsoon indicate that this river water is chemically suitable for irrigation during pre-monsoon with respect to sodium adsorption ratio (SAR), residual sodium carbonate (RSC) and permeability index (PI). The values of all chemical indices declare this river water fitness for use in irrigation both in monsoon and post-monsoon. According to Wilcox diagram, all of the water samples irrespective of tide and sampling stations fall within "permissible to doubtful" category during pre-monsoon while the water samples collected in both tide from all stations fall within "excellent to good" category during monsoon and post-monsoon. The United States Salinity Laboratory (USSL) diagram certifies this river water as C1-S1 (low salinity along with low sodium level) type during monsoon and post-monsoon which makes the river water suitable for use in irrigation in these two seasons while the water is mostly C3-S1, C3-S2 and C3-S3 (high salinity along with low to high sodium level) type in pre-monsoon which makes the river water restricted for use in irrigation in this season.
\end{abstract}

\section{Keywords}

Chitra, Irrigation, Suitability, USSL, Wilcox

\section{Introduction}

Water quality is one of the major environmental determinants that affect the 
ecosystem, agricultural production and socio economic development of a country (Dang et al., 2014; Islam et al., 2016). Bangladesh possess about 5,049,785 ha irrigation based agricultural land which demands sufficient water supply from ground water $(80.60 \%)$ and surface water $(19.40 \%)$ for irrigation to defend the crop's growth and agricultural yield (Shahid et al., 2006; Hasan et al., 2007; Rahman et al., 2014; Vyas \& Jetho, 2015; FAO, 2011). Irrigation water obtained from different sources including springs, streams or wells which contain some chemical substances that may reduce soil fertility and crop yield (Mahmud et al., 2007). Major concern for crop cultivation is the presence of excess salts in water and soils which degrade water and soil quality and decrease crop yields in turn (Tsado et al., 2014). Carbonate, bicarbonate, magnesium, calcium, sulphate, and hardness are significant ions which at high concentration can alter suitability of irrigation water for use (Choudhary et al., 2007). Cations including sodium, calcium and magnesium mainly affect the groundwater quality for use in irrigation and other purposes. At low concentrations some cations are beneficial for crop while at high concentration they can alter the irrigation water quality and soil which exerts toxic effects to plants and thus the management task becomes more difficult (Mitra et al., 2007). Water quality is mainly altered in dry climates because of high evaporation rate and deficient leaching of deposited salts (Qayyum, 1970). The useable irrigation water quality is not identical all over the world but also depends on crops type and permeability of climate and soils. Hence irrigation water quality criteria developed by US salinity laboratory have followed in many countries to evaluate the usability of water in agricultural production (Khalil \& Arther, 2010; Richards, 1954). The river water quality is mainly affected by anthropogenic process like industrial wastewater discharge, agricultural runoffs etc. and natural processes like precipitation, erosion etc (Bricker \& Jones, 1995; Carpenter et al., 1998; Jarvie et al., 1998). Industrial wastewater discharge into water bodies is one of the constant anthropogenic polluting sources while surface runoff is one of the non-point polluting sources which is mainly influenced by climate and topography of the area (Shrestha \& Kazama, 2007; Singh et al., 2004). The lack of irrigation water resources of sustainable quality due to population growth and water quality degradation is becoming a major challenge for agricultural production (Winpenny et al., 2010; Hoekstra \& Mekonnen, 2012). Because of availability and cost effectiveness Chitra River is readily used as a major source of irrigation water around it. But no relevant study was conducted on Chitra River concerning this issue. Hence this study was conducted with an aim to assess the irrigation water quality of Chitra River that will support the crop production here and help to enlarge the local and national economy in turn.

\section{Materials and Methods}

\subsection{Study Area}

The present study was conducted on Chitra River located at southwestern Bangladesh. After originating from the downcast of Chuadanga and Darsana, this 
river flows about $170 \mathrm{~km}$ in southeast and joins with Nabaganga River in Gazirhat of Narail district (Figure 1). Under the study water samples were collected along the Chitra River that covered only Narail Sadar Upazila of Narail District.

The study area possesses a tropical monsoon climate. It experiences pre-monsoon from March to May, which is characterized by highest temperatures; Monsoon from June to September, which is characterized by heavy rainfall when about $80 \%$ rainfall occurs and Post-monsoon from October to November, which is characterized by lesser rainfall and tropical cyclones on coastal region (FAO, 2011).

\subsection{Sampling and Preservation}

Water samples were collected in three seasons namely pre-monsoon (April to May, 2017), monsoon (July to August, 2017) and post-monsoon (October to November, 2017) from five selected sampling stations (Table 1) maintaining about four $\mathrm{km}$ distance between two successive stations along the Chitra River both in high tide and low tide following the standard methods (APHA, 1999). Coordinates of the sampling spots were measured using a GPS device. The water sampling was conducted three times in each season maintaining 12 - 15 days interval and in total 90 samples were collected throughout the study period. For the analysis of cation and anion, samples were collected in two separate PET (polyethylene terephthalate) bottles. $\mathrm{HCl}$ acid was added (to $\mathrm{pH} \sim 2$ ) into the samples for cationic analysis. Then the collected samples were reserved at $4^{\circ} \mathrm{C}$ before to analysis.

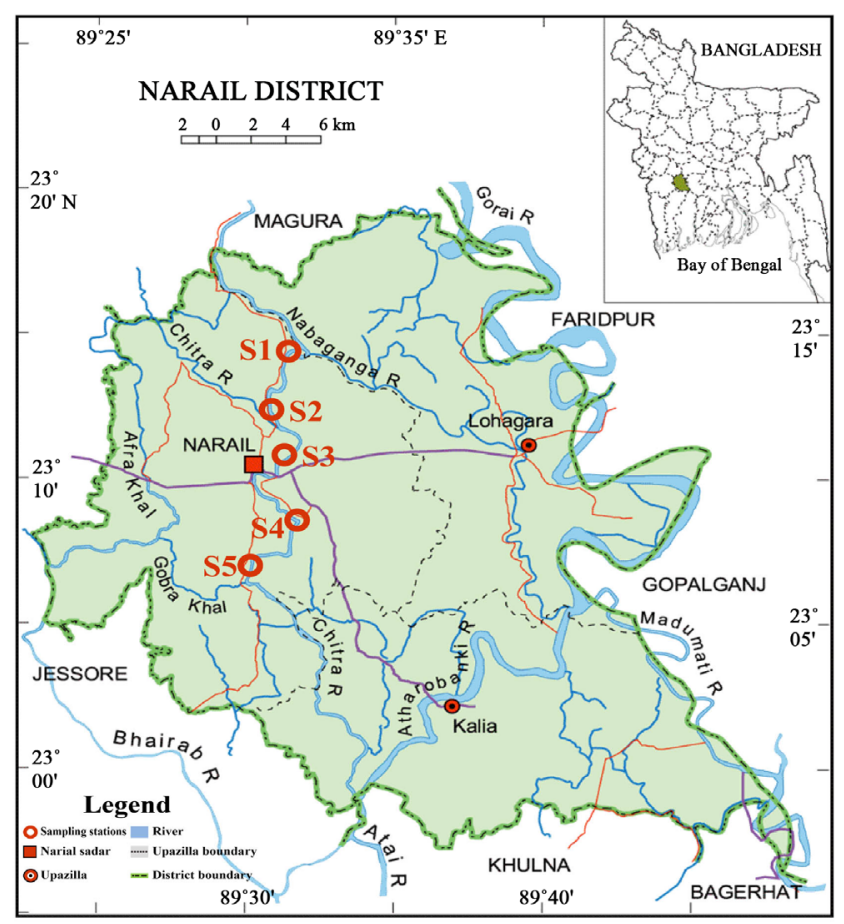

Figure 1. Location map of the sampling spots along the Chitra River (Source: http://narail.amardesh.com/). 
Table 1. Description of the sampling locations.

\begin{tabular}{ccccc}
\hline \multirow{2}{*}{ St. No. } & Dominant features of the stations & Sample ID & \multicolumn{2}{c}{ Co-ordinates } \\
\cline { 4 - 5 } & & Longitude (E) & Latitude (N) \\
\hline S1 & Agriculture, Boating station, Commercial & S1HT, S1LT & $89^{\circ} 31^{\prime} 4.98^{\prime \prime}$ & $23^{\circ} 14^{\prime} 15.11^{\prime \prime}$ \\
S2 & Agriculture, Boating station & S2HT, S2LT & $89^{\circ} 30^{\prime} 51.37^{\prime \prime}$ & $23^{\circ} 11^{\prime} 50.97^{\prime \prime}$ \\
S3 & Commercial & S3HT, S3LT & $89^{\circ} 30^{\prime} 48.95^{\prime \prime}$ & $23^{\circ} 10^{\prime} 8.75^{\prime \prime}$ \\
S4 & Commercial, Agriculture & S4HT, S4LT & $89^{\circ} 31^{\prime} 35.2^{\prime \prime}$ & $23^{\circ} 8^{\prime} 34.8^{\prime \prime}$ \\
S5 & Agriculture, Boating station, Commercial & S5HT, S5LT & $89^{\circ} 29^{\prime} 51.53^{\prime \prime}$ & $23^{\circ} 6^{\prime} 30.62^{\prime \prime}$ \\
\hline
\end{tabular}

\subsection{In-Situ and Laboratory Measurements}

Under physical parameters $\mathrm{pH}, \mathrm{EC}$ and TDS was measured in situ using $\mathrm{pH}$ meter (Model No. pH-5011) and EC/TDS meter (Model No. COND5022). Under major cations $\mathrm{Na}^{+}$and $\mathrm{K}^{+}$was measured using flame photometer (Model No. PEP 7 and PEP 7/C) while $\mathrm{Ca}^{2+}$ and $\mathrm{Mg}^{2+}$ was measured by complexometric titration using $\mathrm{AgNO}_{3}$ solution following the guideline of standard procedure (Ramesh \& Anbu, 1996). Potentiometric titration and Argentometric titration were adopted to determine $\mathrm{HCO}_{3}^{-}$and $\mathrm{Cl}^{-}$respectively (APHA, 1992). UV-Visible spectrophotometer (Model No. UVD-3200) was used to determine $\mathrm{PO}_{4}^{3-}, \mathrm{NO}_{3}^{-}$and $\mathrm{SO}_{4}^{2-}$ concentration in water samples (Ramesh \& Anbu, 1996; APHA, 1992).

\subsection{Methods for Irrigation Water Quality Assessment}

For the evaluation of usability of Chitra River water in irrigation, some common water quality indices available for irrigation water quality assessment including total hardness, sodium percentage (Na\%), sodium adsorption ratio (SAR), residual sodium carbonate (RSC), Kelly's index (KI), permeability index (PI) and magnesium ratio (MR) were calculated using the standard equations (Table 2) and studied. Wilcox diagram and USSL diagram were also studied for the evaluation of this river water quality with respect to irrigational use.

\section{Results and Discussion}

\subsection{General Hydrochemistry}

The results obtained from the investigation showed a significant variation in general hydrochemistry among the three seasons under the study period. Summary of general hydrochemistry of the Chitra River is organized in Table 3. The minimum $\mathrm{pH}$ was found 7.33 in low tide during monsoon whereas the maximum $\mathrm{pH}$ was found 7.97 in low tide during pre-monsoon. The lower $\mathrm{pH}$ in monsoon is due to jute retting on Chitra River because during fiber-separation process various organic acids from the jute plant diffuse into water which affects the water pH (Roy \& Hassan, 2016). Electrical conductivity (EC) of all sampling station during both of high tide and low tide varies from $1028.67 \pm 320.81$ $\mu \mathrm{S} \cdot \mathrm{cm}^{-1}$ and $941.47 \pm 300.87 \mu \mathrm{S} \cdot \mathrm{cm}^{-1}$ in pre-monsoon, $166.20 \pm 0.87 \mu \mathrm{S} \cdot \mathrm{cm}^{-1}$ and 
Table 2. Common water quality indices for the irrigation water quality assessment.

\begin{tabular}{ccc}
\hline Sl. no. & Water quality indices & References \\
\hline 1 & $\mathrm{Na} \%=\left(\left(\mathrm{Na}^{+}+\mathrm{K}^{+}\right) \times 100\right) /\left(\mathrm{Ca}^{2+}+\mathrm{Mg}^{2+}+\mathrm{Na}^{+}+\mathrm{K}^{+}\right)$ & Sawyer \& McCarty, 1967 \\
2 & $\mathrm{SAR}=\mathrm{Na}^{+} / \sqrt{\mathrm{Ca}^{2+}+\mathrm{Mg}^{2+}}$ & Wilcox, 1948 \\
3 & $\mathrm{RSC}=\left(\mathrm{HCO}_{3}^{-}+\mathrm{CO}_{3}^{2-}\right)-\left(\mathrm{Ca}^{2+}+\mathrm{Mg}^{2+}\right)$ & Richards, 1954 \\
4 & $\mathrm{KI}=\mathrm{Na}^{+} /\left(\mathrm{Ca}^{2+}+\mathrm{Mg}^{2+}\right)$ & Apha et al., 1998 \\
6 & $\mathrm{MR}=\left(\mathrm{Mg}^{2+} \times 100\right) /\left(\mathrm{Ca}^{2+}+\mathrm{Mg}^{2+}\right)$ & Kelley, 1963 \\
7 & $\mathrm{PI}=\left(\left(\mathrm{Na}^{+}+\sqrt{\mathrm{HCO}_{3}^{-}}\right) \times 100\right) /\left(\mathrm{Ca}^{2+}+\mathrm{Mg}^{2+}+\mathrm{Na}^{+}\right)$ & Paliwal, 1972 \\
\hline
\end{tabular}

For equation 1, all parameters are figured in $\mathrm{mg} / \mathrm{L}$ and for equation $2-7$, all parameters are figured in meq/L.

Table 3. Summary of water quality parameters of Chitra River during pre-monsoon, monsoon and post-monsoon.

\begin{tabular}{|c|c|c|c|c|c|c|c|c|c|c|c|c|c|c|}
\hline Season & $\begin{array}{l}\text { Tidal } \\
\text { Periods }\end{array}$ & $\begin{array}{l}\text { Statistical } \\
\text { Parameters }\end{array}$ & $\mathrm{pH}$ & $\begin{array}{c}\mathrm{EC} \\
\left(\mu \mathrm{S} \cdot \mathrm{cm}^{-1}\right)\end{array}$ & $\begin{array}{c}\text { TDS } \\
(\mathrm{mg} / \mathrm{L})\end{array}$ & $\begin{array}{c}\mathrm{Na}^{+} \\
(\mathrm{mg} / \mathrm{L})\end{array}$ & $\begin{array}{c}\mathrm{K}^{+} \\
(\mathrm{mg} / \mathrm{L})\end{array}$ & $\begin{array}{c}\mathrm{Ca}^{2+} \\
(\mathrm{mg} / \mathrm{L})\end{array}$ & $\begin{array}{c}\mathrm{Mg}^{2+} \\
(\mathrm{mg} / \mathrm{L})\end{array}$ & $\begin{array}{c}\mathrm{HCO}_{3}^{-} \\
(\mathrm{mg} / \mathrm{L})\end{array}$ & $\begin{array}{c}\mathrm{PO}_{4}^{3-} \\
(\mathrm{mg} / \mathrm{L})\end{array}$ & $\begin{array}{c}\mathrm{SO}_{4}^{2-} \\
(\mathrm{mg} / \mathrm{L})\end{array}$ & $\begin{array}{c}\mathrm{Cl}^{-} \\
(\mathrm{mg} / \mathrm{L})\end{array}$ & $\begin{array}{c}\mathrm{NO}_{3}^{-} \\
(\mathrm{mg} / \mathrm{L})\end{array}$ \\
\hline \multirow{10}{*}{ Pre-moonsoon } & \multirow{6}{*}{$\begin{array}{l}\text { High } \\
\text { Tide }\end{array}$} & MIN & 7.87 & 746.33 & 489.67 & 159.03 & 16.70 & 26.67 & 13.40 & 226.22 & 0.24 & 18.11 & 214.47 & 2.73 \\
\hline & & MAX & 7.93 & 1516.67 & 960.00 & 434.95 & 32.87 & 34.00 & 25.20 & 235.75 & 0.35 & 102.50 & 658.19 & 4.67 \\
\hline & & Mean & 7.91 & 1028.67 & 661.60 & 252.80 & 21.81 & 29.80 & 18.08 & 232.77 & 0.28 & 49.15 & 380.44 & 3.46 \\
\hline & & Median & 7.93 & 905.67 & 577.33 & 207.94 & 18.74 & 28.67 & 16.80 & 234.56 & 0.27 & 34.77 & 310.19 & 3.35 \\
\hline & & SD & 0.03 & 320.81 & 199.23 & 113.38 & 6.78 & 2.98 & 4.92 & 4.04 & 0.04 & 33.55 & 185.04 & 0.73 \\
\hline & & MIN & 7.77 & 681.33 & 427.33 & 141.80 & 15.66 & 25.33 & 12.20 & 230.98 & 0.24 & 24.11 & 174.30 & 3.13 \\
\hline & \multirow{4}{*}{$\begin{array}{l}\text { Low } \\
\text { Tide }\end{array}$} & MAX & 7.97 & 1402.67 & 895.00 & 383.24 & 28.37 & 32.67 & 23.00 & 244.68 & 0.33 & 112.00 & 579.01 & 4.82 \\
\hline & & Mean & 7.87 & 941.47 & 609.20 & 222.52 & 19.98 & 27.93 & 15.96 & 238.19 & 0.27 & 55.80 & 328.41 & 3.77 \\
\hline & & Median & 7.87 & 789.67 & 526.33 & 173.91 & 17.82 & 26.33 & 13.60 & 239.02 & 0.25 & 38.57 & 253.47 & 3.50 \\
\hline & & SD & 0.08 & 300.87 & 192.45 & 99.57 & 5.18 & 2.98 & 4.65 & 5.15 & 0.04 & 35.62 & 167.17 & 0.67 \\
\hline \multirow{9}{*}{ Moonsoon } & \multirow{6}{*}{$\begin{array}{l}\text { High } \\
\text { Tide }\end{array}$} & MIN & 7.37 & 165.00 & 106.33 & 10.85 & 6.26 & 16.67 & 4.33 & 85.40 & 0.63 & 11.08 & 13.96 & 2.35 \\
\hline & & MAX & 7.43 & 167.00 & 111.67 & 12.72 & 6.83 & 18.67 & 4.93 & 89.34 & 0.67 & 13.17 & 15.06 & 2.65 \\
\hline & & Mean & 7.40 & 166.20 & 108.93 & 11.65 & 6.66 & 17.33 & 4.67 & 87.72 & 0.66 & 11.70 & 14.49 & 2.49 \\
\hline & & Median & 7.40 & 166.33 & 109.00 & 11.55 & 6.74 & 17.00 & 4.67 & 87.26 & 0.66 & 11.34 & 14.18 & 2.48 \\
\hline & & SD & 0.03 & 0.87 & 1.89 & 0.68 & 0.23 & 0.85 & 0.27 & 1.66 & 0.02 & 0.85 & 0.53 & 0.11 \\
\hline & & MIN & 7.33 & 160.00 & 105.33 & 10.04 & 6.09 & 16.67 & 4.07 & 81.47 & 0.64 & 11.08 & 13.29 & 2.38 \\
\hline & \multirow{4}{*}{$\begin{array}{l}\text { Low } \\
\text { Tide }\end{array}$} & MAX & 7.40 & 163.67 & 108.00 & 12.25 & 6.30 & 17.00 & 4.80 & 91.19 & 0.66 & 12.15 & 14.18 & 2.49 \\
\hline & & Mean & 7.36 & 162.40 & 106.13 & 11.23 & 6.21 & 16.80 & 4.45 & 85.35 & 0.65 & 11.40 & 14.00 & 2.43 \\
\hline & & Median & 7.37 & 163.33 & 105.33 & 11.09 & 6.26 & 16.67 & 4.47 & 83.32 & 0.66 & 11.25 & 14.18 & 2.42 \\
\hline \multirow{11}{*}{ Post-moonsoon } & & SD & 0.03 & 1.66 & 1.19 & 0.85 & 0.10 & 0.18 & 0.28 & 4.59 & 0.01 & 0.43 & 0.40 & 0.04 \\
\hline & \multirow{6}{*}{$\begin{array}{l}\text { High } \\
\text { Tide }\end{array}$} & MIN & 7.60 & 211.00 & 138.00 & 19.02 & 3.70 & 20.33 & 5.33 & 115.79 & 0.26 & 5.90 & 23.93 & 2.01 \\
\hline & & MAX & 7.67 & 227.67 & 150.33 & 21.83 & 4.28 & 23.67 & 6.20 & 119.96 & 0.31 & 8.26 & 29.80 & 2.14 \\
\hline & & Mean & 7.63 & 216.87 & 143.47 & 20.40 & 3.88 & 21.47 & 5.84 & 118.51 & 0.28 & 6.93 & 26.52 & 2.09 \\
\hline & & Median & 7.63 & 214.33 & 142.33 & 20.30 & 3.81 & 21.00 & 6.00 & 119.20 & 0.28 & 6.92 & 25.70 & 2.11 \\
\hline & & SD & 0.02 & 6.76 & 4.81 & 1.05 & 0.23 & 1.41 & 0.36 & 1.79 & 0.02 & 0.87 & 2.47 & 0.05 \\
\hline & & MIN & 7.60 & 198.67 & 132.00 & 18.08 & 3.60 & 19.67 & 5.00 & 110.87 & 0.25 & 6.67 & 23.04 & 1.98 \\
\hline & \multirow{4}{*}{$\begin{array}{l}\text { Low } \\
\text { Tide }\end{array}$} & MAX & 7.63 & 217.67 & 145.33 & 21.04 & 3.84 & 22.00 & 5.73 & 119.95 & 0.29 & 8.00 & 26.28 & 2.14 \\
\hline & & Mean & 7.61 & 205.47 & 137.20 & 19.61 & 3.69 & 20.67 & 5.43 & 115.81 & 0.27 & 7.25 & 24.75 & 2.06 \\
\hline & & Median & 7.60 & 201.00 & 135.00 & 19.25 & 3.67 & 20.33 & 5.40 & 115.04 & 0.26 & 7.10 & 24.81 & 2.05 \\
\hline & & SD & 0.02 & 8.05 & 6.02 & 1.18 & 0.11 & 0.97 & 0.29 & 3.96 & 0.01 & 0.56 & 1.31 & 0.07 \\
\hline
\end{tabular}


$162.40 \pm 1.66 \mu \mathrm{S} \cdot \mathrm{cm}^{-1}$ in monsoon and $216.87 \pm 6.76 \mu \mathrm{S} \cdot \mathrm{cm}^{-1}$ and $205.47 \pm 8.05$ $\mu \mathrm{S} \cdot \mathrm{cm}^{-1}$ in post-monsoon respectively. Highest TDS was observed $960.00 \mathrm{mg} / \mathrm{L}$ during pre-monsoon while lowest TDS was observed $105.33 \mathrm{mg} / \mathrm{L}$ during monsoon. The average $\mathrm{Na}^{+}$concentrations were observed $252.80 \pm 113.38 \mathrm{mg} / \mathrm{L}$ and $222.52 \pm 99.57 \mathrm{mg} / \mathrm{L}, 11.65 \pm 0.68 \mathrm{mg} / \mathrm{L}$ and $11.23 \pm 0.85 \mathrm{mg} / \mathrm{L}$, and $20.40 \pm 1.05$ $\mathrm{mg} / \mathrm{L}$ and $19.61 \pm 1.18 \mathrm{mg} / \mathrm{L}$ in pre-monsoon, monsoon and post-monsoon respectively in their respective high tide and low tide.

Maximum potassium ion concentration was noticed $32.87 \mathrm{mg} / \mathrm{L}$ in pre-monsoon during high tide and minimum concentration was noticed $3.60 \mathrm{mg} / \mathrm{L}$ in post-monsoon during low tide. Highest potassium concentration in the river water during pre-monsoon may be because of upward sea water movement during dry season which contains high content of potassium due to the dissolution of potassium containing sedimentary rocks in the sea water (Hem, 1970). Again under the study higher concentration of potassium was observed in monsoon season compared to post-monsoon which may be cause of potassium containing fertilizer runoff mixing with rain water during monsoon. Maximum calcium concentration was found $34.00 \mathrm{mg} / \mathrm{L}$ in pre-monsoon while minimum concentration was found $16.67 \mathrm{mg} / \mathrm{L}$ in monsoon. Also maximum magnesium concentration was found $25.20 \mathrm{mg} / \mathrm{L}$ in pre-monsoon and minimum concentration was found $4.07 \mathrm{mg} / \mathrm{L}$ in monsoon. Dissolved magnesium concentration is usually lower than dissolved calcium for a majority of the natural waters because of the high solubility of $\mathrm{Mg}$ salts into water than Ca salts (Ramesh \& Anbu, 1996). Bicarbonate ion concentration was observed to vary $232.77 \pm 4.04 \mathrm{mg} / \mathrm{L}$ for high tides and $238.19 \pm 5.15 \mathrm{mg} / \mathrm{L}$ for low tides in pre-monsoon, $87.72 \pm 1.66$ $\mathrm{mg} / \mathrm{L}$ for high tide and $85.35 \pm 4.59 \mathrm{mg} / \mathrm{L}$ for low tide in monsoon and $118.51 \pm$ $1.79 \mathrm{mg} / \mathrm{L}$ for high tide and $115.81 \pm 3.96 \mathrm{mg} / \mathrm{L}$ for low tide in post-monsoon. Variation in bicarbonate concentration in river water may be due to wastewater discharge into the river and bicarbonate weathering (Datta \& Subramanian, 1997; Li \& Zhang, 2009). In the study area phosphate ion concentration was observed with an average value $0.28 \pm 0.04 \mathrm{mg} / \mathrm{L}$ (high tide) and $0.27 \pm 0.04 \mathrm{mg} / \mathrm{L}$ (low tide) in pre-monsoon, $0.66 \pm 0.02 \mathrm{mg} / \mathrm{L}$ (high tide) and $0.65 \pm 0.01 \mathrm{mg} / \mathrm{L}$ (low tide) in monsoon and $0.28 \pm 0.02 \mathrm{mg} / \mathrm{L}$ (high tide) and $0.27 \pm 0.01 \mathrm{mg} / \mathrm{L}$ (low tide) in post-monsoon. The higher concentration of phosphate in the river water during monsoon might be coming from the phosphate containing fertilizer used for jute cultivation (Roy \& Hassan, 2016). Sulfate concentration was found to vary widely among the three sampling seasons. Maximum sulfate concentration was recorded $112.00 \mathrm{mg} / \mathrm{L}$ in low tide during pre-monsoon and minimum concentration was recorded $5.90 \mathrm{mg} / \mathrm{L}$ during post-monsoon in high tide. Higher concentration of sulfate in the river water during pre-monsoon may be due to wreathing coupled with erosional deposits into the river (Varol et al., 2012). Chloride ion concentration was recorded $380.44 \pm 185.04 \mathrm{mg} / \mathrm{L}$ for high tide and $328.41 \pm 167.17 \mathrm{mg} / \mathrm{L}$ for low tide in pre-monsoon, $14.49 \pm 0.53 \mathrm{mg} / \mathrm{L}$ for high tide and $14.00 \pm 0.40 \mathrm{mg} / \mathrm{L}$ for low tide in monsoon and $26.52 \pm 2.47$ $\mathrm{mg} / \mathrm{L}$ for high tide and $24.75 \pm 1.31 \mathrm{mg} / \mathrm{L}$ for low tide in post-monsoon. Maxi- 
mum concentration of chloride ion was recorded $658.19 \mathrm{mg} / \mathrm{L}$ in pre-monsoon during high tide and minimum concentration was recorded $13.29 \mathrm{mg} / \mathrm{L}$ in monsoon during low tide. In the coastal water zone, the chloride concentration in water is directly proportional to its salinity (Ayers \& Westcot, 1994). Since chloride ion is a major anionic constituent in sea water, higher chloride ion concentration in river water indicates a significant influence of sea water on the river hydrochemistry (Bu et al., 2010; Appelo \& Postma, 2010). In the study area nitrate ion concentration varied between $3.46 \pm 0.73 \mathrm{mg} / \mathrm{L}$ for high tide and 3.77 $\pm 0.67 \mathrm{mg} / \mathrm{L}$ for low tide in pre-monsoon, $2.49 \pm 0.11 \mathrm{mg} / \mathrm{L}$ for high tide and $2.43 \pm 0.04 \mathrm{mg} / \mathrm{L}$ for low tide in monsoon and $2.09 \pm 0.05 \mathrm{mg} / \mathrm{L}$ for high tide and $2.06 \pm 0.07 \mathrm{mg} / \mathrm{L}$ for low tide in post-monsoon. Agricultural runoff, industrial wastewater and sewage disposal are the major sources of river water contamination with nitrate ion while microbial consumption and de-nitrification are the main routes of nitrate reduction (Rahman et al., 2014; Varol et al., 2012).

\subsection{Suitability for Irrigation}

In order to evaluate the Chitra River water suitability for use in irrigation purpose, water quality parameters that mainly affect the crop production need to be studied. The statistical summary of calculated chemical indices related to irrigation water quality is listed in Table 4.

Depending on $\mathrm{pH}$ value, irrigation water is mainly classified into three classes (Table 5). Based on this classification all of the water samples irrespective of season and tide fall within "no problem" class. Electrical conductivity (EC) expresses the total concentration of all soluble salts and it is used widely to classify the irrigation water (Varol et al., 2012). According to Richards (1954), during pre-monsoon $20 \%$ of water samples collected in high tide and $40 \%$ of water samples collected in low tide are marked as "good" and the rest $80 \%$ water samples for high tide and 60\% water samples for low tide are categorized as "permissible" for use in irrigation. Irrespective of tide during monsoon and post-monsoon $100 \%$ of the water samples were marked as "excellent" for use in irrigation. High EC bearing water used in crop production can reduce the crops growth rate, lower the crop yield and create nutritional disorders under specific condition (Eaton, 1950). TDS and EC values are interrelated and both values indicate the salinity of water when non-ionic dissolved constituents remain absent (Meybeck et al., 1992). Based on TDS values, most of the samples during pre-monsoon for both of high tide and low tide are categorized as "permissible" and all of the water samples during monsoon and post-monsoon for high tide and low tide are categorized as "good" for use in irrigation. The water bearing high sodium level can damage the structure of soil by replacing calcium ion and magnesium ion present in the soil which affects the soil fertility and crop yield capacity in turn (Ayers \& Westcot, 1994; Gupta, 2005). During pre-monsoon sodium content in $60 \%$ water samples for both of high tide and low tide fall within "moderate" level and the rest $40 \%$ for both tide falls within "severe" limit while $100 \%$ of water samples irrespective of tide contain safe range of sodium 
Table 4. Statistical summary of calculated indices.

\begin{tabular}{|c|c|c|c|c|c|c|c|c|c|}
\hline Season & Tidal Cycle & Descriptive Statistics & $\mathrm{TH}\left(\right.$ as $\mathrm{CaCO}_{3}$ ) & $\mathrm{Na} \%$ & SAR & RSC & PI & $\mathrm{KI}$ & MR \\
\hline \multirow{10}{*}{ Pre-moonsoon } & \multirow{5}{*}{ High Tide } & MIN & 2003.33 & 74.98 & 6.25 & -0.09 & 91.47 & 2.82 & 45.58 \\
\hline & & MAX & 2960.00 & 83.87 & 13.72 & 1.40 & 94.78 & 4.98 & 55.26 \\
\hline & & Mean & 2394.00 & 78.27 & 8.79 & 0.82 & 92.89 & 3.54 & 49.66 \\
\hline & & Median & 2273.33 & 77.07 & 7.60 & 1.03 & 92.69 & 3.19 & 49.41 \\
\hline & & SD & 393.95 & 3.64 & 3.07 & 0.60 & 1.38 & 0.88 & 4.18 \\
\hline & \multirow{5}{*}{ Low Tide } & MIN & 1876.67 & 74.20 & 5.77 & 0.24 & 92.06 & 2.70 & 44.37 \\
\hline & & MAX & 2783.33 & 83.05 & 12.51 & 1.64 & 96.40 & 4.69 & 53.99 \\
\hline & & Mean & 2194.67 & 77.81 & 8.11 & 1.18 & 94.53 & 3.42 & 48.11 \\
\hline & & Median & 1996.67 & 76.60 & 6.83 & 1.56 & 95.53 & 3.09 & 46.26 \\
\hline & & SD & 380.49 & 3.52 & 2.75 & 0.61 & 1.98 & 0.80 & 4.35 \\
\hline \multirow{9}{*}{ Moonsoon } & \multirow{5}{*}{ High Tide } & MIN & 1066.67 & 34.46 & 0.60 & 0.12 & 94.10 & 0.39 & 28.51 \\
\hline & & MAX & 1156.67 & 35.78 & 0.68 & 0.22 & 98.03 & 0.42 & 33.04 \\
\hline & & Mean & 1100.00 & 35.02 & 0.64 & 0.18 & 96.84 & 0.40 & 31.00 \\
\hline & & Median & 1096.67 & 35.12 & 0.64 & 0.19 & 97.23 & 0.40 & 31.82 \\
\hline & & SD & 34.40 & 0.53 & 0.03 & 0.04 & 1.57 & 0.01 & 2.09 \\
\hline & \multirow{5}{*}{ Low Tide } & MIIN & 1036.67 & 32.65 & 0.56 & 0.11 & 95.99 & 0.36 & 28.91 \\
\hline & & MAX & 1080.00 & 36.02 & 0.68 & 0.26 & 99.79 & 0.43 & 32.43 \\
\hline & & Mean & 1062.67 & 34.82 & 0.63 & 0.19 & 98.31 & 0.40 & 30.62 \\
\hline & & Median & 1073.33 & 35.19 & 0.62 & 0.19 & 98.67 & 0.41 & 30.45 \\
\hline \multirow{11}{*}{ Post-moonsoon } & & SD & 18.47 & 1.27 & 0.04 & 0.06 & 1.52 & 0.03 & 1.28 \\
\hline & \multirow{5}{*}{ High Tide } & MIN & 1283.33 & 37.83 & 0.95 & 0.23 & 108.62 & 0.54 & 30.39 \\
\hline & & MAX & 1493.33 & 40.09 & 1.03 & 0.44 & 118.91 & 0.59 & 33.21 \\
\hline & & Mean & 1365.33 & 38.76 & 1.00 & 0.38 & 115.83 & 0.57 & 31.21 \\
\hline & & Median & 1330.00 & 38.55 & 1.02 & 0.44 & 118.23 & 0.57 & 30.77 \\
\hline & & SD & 83.09 & 0.91 & 0.03 & 0.09 & 4.40 & 0.02 & 1.17 \\
\hline & \multirow{5}{*}{ Low Tide } & MIN & 1233.33 & 37.82 & 0.93 & 0.37 & 115.43 & 0.54 & 29.76 \\
\hline & & MAX & 1386.67 & 40.06 & 1.03 & 0.49 & 121.72 & 0.60 & 30.77 \\
\hline & & Mean & 1304.67 & 38.94 & 0.99 & 0.41 & 117.71 & 0.57 & 30.44 \\
\hline & & Median & 1286.67 & 39.00 & 1.00 & 0.39 & 117.11 & 0.58 & 30.68 \\
\hline & & SD & 62.52 & 0.81 & 0.04 & 0.05 & 2.38 & 0.02 & 0.42 \\
\hline
\end{tabular}

during monsoon and post-monsoon making the water suitable for use in irrigations. Irrigation water with high sulfate ion concentration limits the absorption of calcium and increases the uptake of sodium and potassium by plants (Tiwari \& Manzoor, 1988). According to Eaton (1942), irrespective of season and tide Chitra River water was evaluated as suitable for use in irrigation with respect to sulphate concentration. Chloride at lower concentration is an essential nutrient 
Table 5. Analysis of water quality classes of Chitra River with respect to agricultural use during pre-monsoon, monsoon and post-monsoon.

\begin{tabular}{|c|c|c|c|c|c|c|c|c|}
\hline \multirow{2}{*}{ Parameters } & \multirow{2}{*}{ Rate of hazard } & \multirow{2}{*}{ Water quality classes } & \multicolumn{2}{|c|}{ Pre-monsoon } & \multicolumn{2}{|c|}{ Monsoon } & \multicolumn{2}{|c|}{ Post-monsoon } \\
\hline & & & High Tide & Low Tide & High Tide & Low Tide & High Tide & Low Tide \\
\hline \multirow{3}{*}{$\mathrm{pH}^{\mathrm{a}, \mathrm{b}}$} & $6.5-8.4$ & No problem & All & All & All & All & All & All \\
\hline & $5.1-6.4$ and $8.5-9.5$ & Moderate & & & & & & \\
\hline & $0-5.0$ and $9.5+$ & Severe & & & & & & \\
\hline \multirow{4}{*}{$\begin{array}{c}\mathrm{EC}^{\mathrm{c}} \\
\left(\mu \mathrm{S} \cdot \mathrm{cm}^{-1}\right)\end{array}$} & $<250$ & Excellent & & & All & All & All & All \\
\hline & $250-750$ & Good & S1HT & S1LT,S2LT & & & & \\
\hline & $750-2250$ & Permissible & S2HT - S5HT & S3LT - S5LT & & & & \\
\hline & $>2250$ & Unsuitable & & & & & & \\
\hline \multirow{3}{*}{$\begin{array}{l}\mathrm{TDS}^{\mathrm{a}, \mathrm{b}} \\
(\mathrm{mg} / \mathrm{L})\end{array}$} & $<450$ & Good & & S1LT & All & All & All & All \\
\hline & $450-2000$ & Permissible & All & S2LT-S5LT & & & & \\
\hline & $>2000$ & Unsuitable & & & & & & \\
\hline \multirow{3}{*}{$\begin{array}{c}\mathbf{N a}^{+a, b} \\
(\mathrm{meq} / \mathrm{L})\end{array}$} & $<3$ & No problem & & & All & All & All & All \\
\hline & $3-9$ & Moderate & S1HT - S3HT & S1LT - S3LT & & & & \\
\hline & $>9$ & Severe & S4HT, S5HT & S4LT, S5LT & & & & \\
\hline \multirow{3}{*}{$\begin{array}{c}\mathrm{SO}_{4}^{2-\mathrm{d}} \\
(\mathrm{meq} / \mathrm{L})\end{array}$} & $<4$ & Excellent & All & All & All & All & All & All \\
\hline & $4-12$ & Good to injurious & & & & & & \\
\hline & $>12$ & Injurious to unsuitable & & & & & & \\
\hline \multirow{3}{*}{$\begin{array}{c}\mathbf{C l}^{-a, b} \\
(\mathrm{meq} / \mathrm{L})\end{array}$} & $<4$ & No problem & & & All & All & All & All \\
\hline & $4-10$ & Moderate & S1HT - S3HT & S1LT - S3LT & & & & \\
\hline & $>10$ & severe & S4HT, S5HT & S4LT, S5LT & & & & \\
\hline \multirow{3}{*}{$\begin{array}{l}\mathrm{NO}_{3}^{-\mathrm{a}, \mathrm{b}} \\
(\mathrm{mg} / \mathrm{L})\end{array}$} & $<5$ & No problem & All & All & All & All & All & All \\
\hline & $5-30$ & moderate & & & & & & \\
\hline & $>30$ & severe & & & & & & \\
\hline \multirow{5}{*}{$\mathrm{Na} \%^{\mathrm{e}}$} & $<20$ & Excellent & & & & & & \\
\hline & $20-40$ & Good & & & All & All & S2HT - S5HT & S2LT - S5LT \\
\hline & $40-60$ & Permissible & & & & & S1HT & S1LT \\
\hline & $60-80$ & Doubtful & S1HT - S4HT & S1LT - S4LT & & & & \\
\hline & $>80$ & Unsuitable & S5HT & S5LT & & & & \\
\hline \multirow{4}{*}{ SAR $^{c}$} & $<10$ & Excellent & S1HT - S4HT & S1LT - S4LT & All & All & All & All \\
\hline & $10-18$ & Good & S5HT & S5LT & & & & \\
\hline & $18-26$ & Doubtful & & & & & & \\
\hline & $>26$ & Unsuitable & & & & & & \\
\hline \multirow{3}{*}{$\operatorname{RSC}^{\mathrm{f}}$} & $<1.25$ & Safe & S2HT - S5HT & S4LT - S5LT & All & All & All & All \\
\hline & $1.25-2.50$ & Permissible & S1HT & S1LT - S3LT & & & & \\
\hline & $>2.50$ & Unsuitable & & & & & & \\
\hline
\end{tabular}

${ }^{\mathrm{a}}$ Ayers \& Westcot ,1994; ${ }^{\mathrm{b}}$ Sundaray et al., 2009; ${ }^{\mathrm{C}}$ Richards, 1954; ${ }^{\mathrm{d}}$ Eaton, 1942; ${ }^{\mathrm{e} W i l c o x}, 1948$; ${ }^{\mathrm{f} W i l c o x}, 1955$. 
for plant but excess chloride may cause chloride toxicity to the plant. A chloride concentration of about $140-350 \mathrm{mg} / \mathrm{L}$ in irrigation water is injurious to plants while $>350 \mathrm{mg} / \mathrm{l}$ is fatal to plants which can cause leaf tissue drying or leaf burning (Mass, 1990). According to classification given by Ayers and Westcot (1994), Chitra River water shows moderate to severe chloride toxicity during pre-monsoon and does not show any chloride toxicity during monsoon and post-monsoon. Nitrogen is another essential nutrient for plant that stimulates plant growth but excess nitrogen can cause injury to plant. Latent soil nitrogen and supplementary nitrogen containing fertilizers are the major sources of nitrogen. Nitrogen contaminants in irrigation water possess the same effect on plant as like as latent soil and supplementary fertilizer nitrogen (Ayers \& Westcot, 1994). The nitrogen concentrations in this river water are categorized under "no problem" class (Table 5) during the study period which reveals that the Chitra River water do not possess any nitrate hazard. Based on hardness, Durfer and Backer classified water as "soft" (0 - $\left.60 \mathrm{mg} / \mathrm{Las} \mathrm{CaCO}_{3}\right)$, "moderately hard" $\left(60-150 \mathrm{mg} / \mathrm{L}\right.$ as $\left.\mathrm{CaCO}_{3}\right)$, "hard" (120 - $180 \mathrm{mg} / \mathrm{L}$ as $\left.\mathrm{CaCO}_{3}\right)$ and "very hard" $\left(>180 \mathrm{mg} / \mathrm{L}\right.$ as $\mathrm{CaCO}_{3}$ ) (Durfer \& Backer, 1964). According to this classification Chitra River water fall within "very hard" class and assigned as unsuitable for use in irrigation. SAR and $\mathrm{Na} \%$ indices are generally related with sodium hazard possessing in irrigation water. Based on $\mathrm{Na} \%, 100 \%$ of water samples during pre-monsoon fall within "doubtful" to "unsuitable" category and marks this water unsuitable for use in irrigation during this season while $100 \%$ of water samples during monsoon and post-monsoon are categorized within "good" to "permissible" category and marks this water suitable for use in irrigation purpose during those two seasons. SAR is a expression of exchange ability of sodium ion with calcium and magnesium ions in soil which measures a water's suitability for use in irrigation purpose with respect to sodium hazard (Tiwari \& Manzoor, 1988; Sundaray et al., 2009; Haritash et al., 2008). Based on SAR, All water samples irrespective of season and tide fall within "excellent" to "good" category and was assigned as suitable for irrigation (Table 5). In water bearing high carbonate concentration, the carbonate precipitates with calcium and magnesium as their carbonate. When all of the calcium and magnesium ions get precipitated, the remaining carbonate or bicarbonate ions precipitate with sodium forming sodium carbonate (RSC) or bicarbonate in solution (Haritash et al., 2008). Use of irrigation water having high RSC value might cause sodium carbonate accumulation in soil which turns soil into black colored (Eaton, 1950). Depending on RSC values, all of the water samples collected from Chitra River irrespective of tide and season fall within "safe" to "permissible" class making this water compatible for use in irrigation. Based on permeability index (PI), Doneen (1964) classified irrigation water into three classes namely Class I, Class II and Class III, where water of Class I and Class II are marked as "good" for irrigation having $50 \%-75 \%$ or more of permeability index range and Class III is categorized as "unsuitable" for irrigation having 25\% of maximum permeability index range 
(Doneen, 1964). Under the study, during pre-monsoon the permeability index values fall between 91.47 to 94.78 and 92.06 to 96.40 for high tide and low tide respectively which are categorized as Class I and Class II indicating its "suitability" for use in irrigation. PI values of the water samples collected from Chitra River during Monsoon ranges from 94.10 to 98.03 in high tide and 95.99 to 99.79 in low tide respectively while PI values in post-monsoon ranges from 108.62 to 118.91 and 115.43 to 121.72 in high tide and low tide respectively. Therefore all of the water samples collected from Chitra River during monsoon and post-monsoon fall under Class I and Class II category which certifies the "suitability" of this water for use in irrigation purpose during these two agricultural seasons. Kelly's index (KI) is another significant parameter to measure the usability of irrigation water. Waters with $\mathrm{KI}<1$ are categorized as "suitable" for crop irrigation, while waters with KI $>1$ are considered as "unsuitable" (Kelley, 1963; Paliwal \& Singh, 1967). The calculated KI values of all water samples collected from Chitra River irrespective of tide during pre-monsoon were $>1$ indicating that the water is "unsuitable" for use in crop irrigation during this season. In the monsoon and post-monsoon, the calculated KI values for all water samples collected during high tide and low tide were $<1$ indicating its suitability for use in irrigation purpose. According to Paliwal, irrigation water having MR value more than $50 \%$ makes the soil more alkaline and therefore adversely affects the crop yield (Paliwal, 1972). During pre-monsoon, $40 \%$ water samples for both of high tide and low tide possess a MR value more than $50 \%$ indicating its unsuitability for irrigation. The rest $60 \%$ samples in high tide and low tide were evaluated as suitable for irrigation. During monsoon and post-monsoon all of the water samples for high tide and low tide were assigned as safe for use in irrigation bearing a MR value less than $50 \%$.

\subsection{Assessment of Irrigation Water Quality with Respect to FAO and DoE Standards}

The usual irrigation water quality parameters for the collected water samples from Chitra River were compared with the DoE standards (DoE, 1997) and FAO standards (Ayers \& Westcot, 1985) enlisted in Table 6. According to DoE, 1997 and FAO, 1985 the values of all irrigation water quality parameters including $\mathrm{pH}, \mathrm{EC}, \mathrm{TDS}, \mathrm{Na}^{+}, \mathrm{K}^{+}, \mathrm{Ca}^{2+}, \mathrm{Mg}^{2+}, \mathrm{HCO}_{3}^{-}, \mathrm{SO}_{4}^{2-}, \mathrm{Cl}^{-}, \mathrm{NO}_{3}^{-}$and SAR for the water samples collected from Chitra River fall within the acceptable limit during pre-monsoon, monsoon and post-monsoon. Thus, it can be recommended that the Chitra River water is chemically suitable for crop production during pre-monsoon, monsoon and post-monsoon.

\subsection{Evaluation of Irrigation Water Quality from Graphical Representations}

From the Wilcox diagram (Figure 2) it is observed that during pre-monsoon, irrespective of the sampling locations and tide, 100\% water samples collected from Chitra River fall within "permissible to doubtful" category whereas all of 


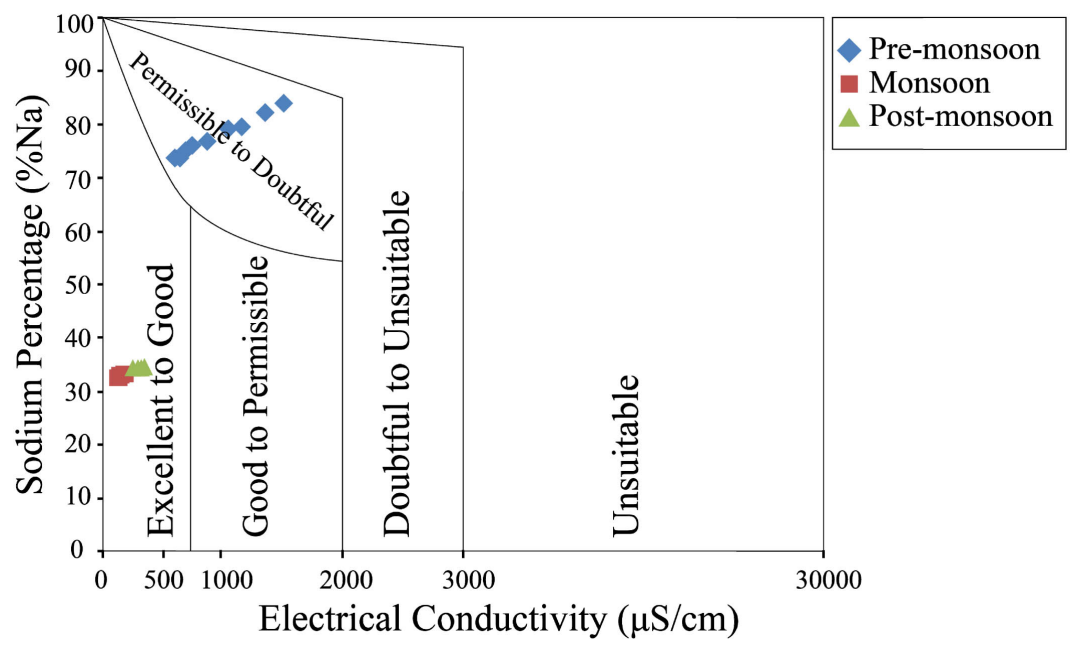

Figure 2. Wilcox diagram for the classification of Chitra River water.

Table 6. Water quality evaluation of Chitra River for irrigation purpose comparing with FAO and DoE standards.

\begin{tabular}{|c|c|c|c|c|c|}
\hline \multirow{2}{*}{ Parameters } & \multirow{2}{*}{$\mathrm{FAO}^{\mathrm{a}}$} & \multirow{2}{*}{$\operatorname{DoE}^{b}$} & \multicolumn{3}{|c|}{ Percentage (\%) of samples within the ranges } \\
\hline & & & Pre-monsoon & Monsoon & Post-monsoon \\
\hline $\mathrm{pH}$ & $6.0-8.5$ & $6.5-8.5$ & 100 & 100 & 100 \\
\hline $\mathrm{EC}\left(\mu \mathrm{S} \cdot \mathrm{cm}^{-1}\right)$ & $0-3000$ & 2250 & 100 & 100 & 100 \\
\hline TDS (mg/L) & $0-2000$ & 2100 & 100 & 100 & 100 \\
\hline $\mathrm{Na}^{+}(\mathrm{meq} / \mathrm{L})$ & $0-40$ & 43.5 & 100 & 100 & 100 \\
\hline $\mathrm{K}^{+}(\mathrm{meq} / \mathrm{L})$ & $0-20$ & & 100 & 100 & 100 \\
\hline $\mathrm{Ca}^{2+}(\mathrm{meq} / \mathrm{L})$ & $0-20$ & & 100 & 100 & 100 \\
\hline $\mathrm{Mg}^{2+}(\mathrm{meq} / \mathrm{L})$ & $0-05$ & & 100 & 100 & 100 \\
\hline $\mathrm{HCO}_{3}^{-} \quad(\mathrm{meq} / \mathrm{L})$ & $0-10$ & & 100 & 100 & 100 \\
\hline $\mathrm{SO}_{4}^{2-} \quad(\mathrm{meq} / \mathrm{L})$ & $0-20$ & & 100 & 100 & 100 \\
\hline $\mathrm{Cl}^{-} \quad(\mathrm{meq} / \mathrm{L})$ & $0-30$ & & 100 & 100 & 100 \\
\hline $\mathrm{NO}_{3}-\mathrm{N}(\mathrm{mg} / \mathrm{L})$ & $0-10$ & 10 & 100 & 100 & 100 \\
\hline SAR (meq/L) & $0-15$ & 23 & 100 & 100 & 100 \\
\hline
\end{tabular}

${ }^{\mathrm{a} A y e r s} \&$ Westcot, 1985; ${ }^{\mathrm{b}}(\mathrm{DoE}, 1997)$.

the samples, fall within "excellent to good" category during monsoon and post-monsoon. Therefore, it can be assumed that the Chitra River water can be used in crop production during these three agricultural seasons. The USSL (US Salinity Laboratory Staff) diagram (Figure 3), a plot of EC (salinity hazard) against SAR (sodium hazard or alkalinity hazard) reflects the effect of EC and SAR (Richards, 1954). The SAR and EC values for all of the water samples collected from Chitra River were plotted in a diagram (Figure 3). Irrespective of tide all of the water samples collected during monsoon and post-monsoon fall into C1-S1 field indicating low salinity hazard along with low sodium level. 


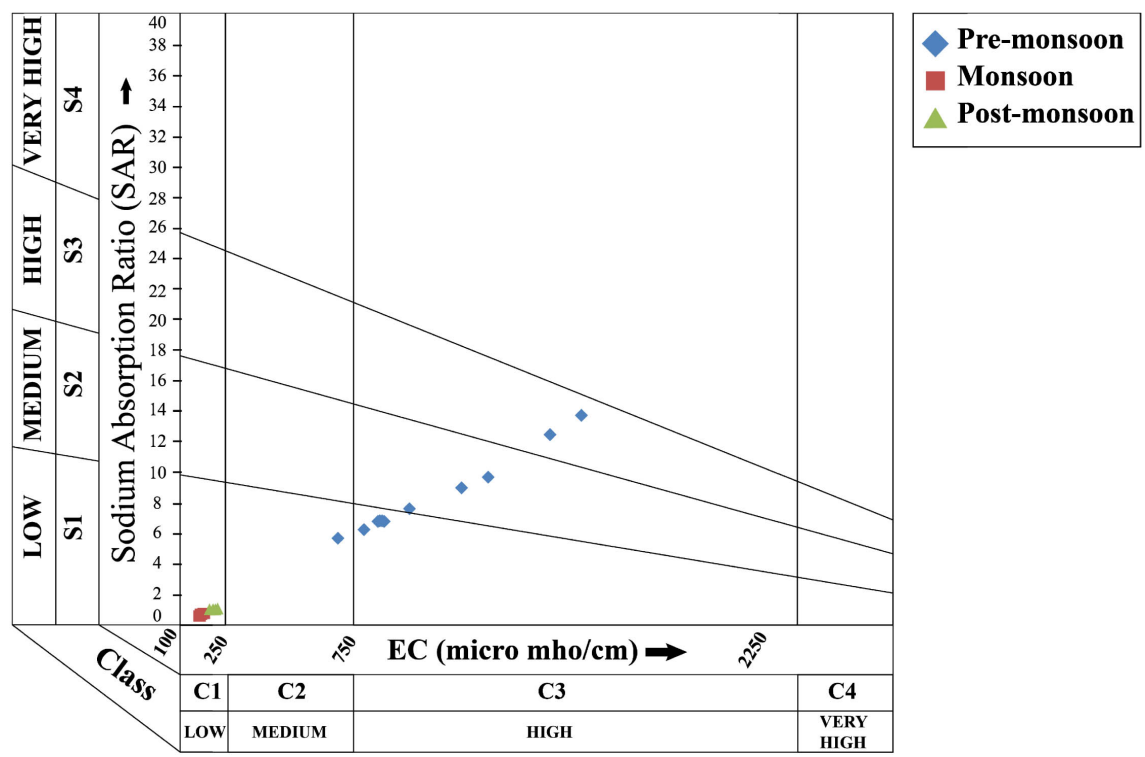

Figure 3. US salinity laboratory diagram for the classification of Chitra River water.

While during pre-monsoon $10 \%$ of the sample fall into C2-S1 (medium salinity hazard along with low sodium level), $40 \%$ of the sample fall into C3-S1 (high salinity hazard along with low sodium level) field, $30 \%$ of the sample fall within C3-S2 (high salinity hazard along with medium sodium level) and the rest 20\% of the sample fall within C3-S3 (high salinity hazard along with high sodium level) field in pre-monsoon. Salinity in water reduces the water uptake rate by the plant because of osmotic effect, possesses ion specific toxic effects and also causes nutritional imbalance in plant (Natarajan et al., 2005). Sodium hazard affects the texture of soils, while high salinity content in irrigation water influences the crop growth directly. Therefore, water with high salinity is completely unsuitable for use in crop irrigation purpose (Haritash et al., 2008).

\section{Conclusion}

The findings of the present study on Chitra River show that the seasonal variation of the hydrochemistry of this river system is significant. In pre-monsoon $\mathrm{Na}^{+}$is the dominant cation with a cationic order $\mathrm{Na}^{+}>\mathrm{Ca}^{2+}>\mathrm{K}^{+}>\mathrm{Mg}^{2+}$ while $\mathrm{Cl}^{-}$is the most dominant anion with a anionic order $\mathrm{Cl}^{-}>\mathrm{HCO}_{3}^{-}>\mathrm{SO}_{4}^{2-}>\mathrm{NO}_{3}^{-}>\mathrm{PO}_{4}^{3-}$. During monsoon and post-monsoon the cationic order has been found as $\mathrm{Ca}^{2+}>\mathrm{Na}^{+}>\mathrm{K}^{+}>\mathrm{Mg}^{2+}$ and $\mathrm{Ca}^{2+}>\mathrm{Na}^{+}>\mathrm{Mg}^{2+}>\mathrm{K}^{+}$respectively while the anionic order has been found to be $\mathrm{HCO}_{3}^{-}>\mathrm{Cl}^{-}>\mathrm{SO}_{4}^{2-}>\mathrm{NO}_{3}^{-}>\mathrm{PO}_{4}^{3-}$ both in monsoon and post-monsoon. Like major rivers, irrespective of tidal cycle, the water of Chitra River is alkaline in nature with $\mathrm{pH} 7.77$ to 7.97 during pre-monsoon, 7.33 to 7.43 during monsoon and 7.60 to 7.67 during post-monsoon. In pre-monsoon EC varies with an average value of $1028.67 \pm 320.81$ for high tide and $941.47 \pm 300.87$ for low tide, in monsoon $166.20 \pm 0.87$ for high tide and $162.40 \pm 1.66$ for low tide and in post-monsoon $216.87 \pm 6.76$ for high tide and $205.47 \pm 8.05$ for low tide. The 
water quality parameters including $\mathrm{pH}, \mathrm{EC}, \mathrm{TDS}, \mathrm{Na}^{+}, \mathrm{K}^{+}, \mathrm{Ca}^{2+}, \mathrm{Mg}^{2+}, \mathrm{HCO}_{3}^{-}$, $\mathrm{SO}_{4}^{2-}, \mathrm{Cl}^{-}, \mathrm{NO}_{3}^{-}$and SAR estimated for all of the water samples satisfy the value limit given by DoE, 1997 and FAO, 1985 for irrigation purpose during monsoon, monsoon and post-monsoon indicating its suitability for use in agriculture. During pre-monsoon the values of SAR, RSC and PI indicate that this river water is suitable for use in crop irrigation purpose while the river water is identified as "unsuitable" with respect to KI and "doubtful to unsuitable" with respect to $\mathrm{Na} \%$. The values of all chemical indices permit the Chitra River water for use in agricultural irrigation purpose during monsoon and post-monsoon. Based on Wilcox diagram, the water samples fall within "permissible to doubtful" category during pre-monsoon while all of the water samples fall within "excellent to good" category during monsoon and post-monsoon indicating its usability for irrigation during these agricultural seasons. Again according to USSL diagram, the river water can be used in irrigation during monsoon and post-monsoon because of low salinity with low sodium while during pre-monsoon this river water turns restricted for use in irrigation because of its high salinity coupled with low to high sodium. This river supports the regional crop production in this area. Hence, from this study it could be suggested that further studies regarding heavy metal pollution and periodic monitoring of water quality should be carried out. Awareness program and strict enforcement against domestic and municipal wastewater disposal into the river water should be adopted. Alternative sources for irrigation water and efficient irrigation methods should be found out.

\section{Acknowledgements}

The present study was financially supported by the Ministry of National Science and Technology, Bangladesh through NST Fellowship. The authors gratefully acknowledge the Chemistry Discipline and Environmental Science Discipline, Khulna University, Bangladesh for providing all types of support throughout the study period.

\section{Conflicts of Interest}

The authors declare no conflicts of interest regarding the publication of this paper.

\section{References}

APHA (1992). Standard Methods for the Examination of Water and Wastewater (18th ed.). Washington DC.

APHA (1999). Standard Methods for the Examination of Water and Wastewater (p. 541).

Apha, L. S., Clesceri, A. E., \& Greenberg, A. D. (1998). Standard Methods for the Examination of Water and Wastewater (20th ed.). Washington DC: American Water Works Association.

Appelo, C. A. J., \& Postma, D. (2010). Geochemistry, Groundwater and Pollution (2nd ed., Vol. 32, No. 2). Boca Raton, FL: CRC Press.

Ayers, R. S., \& Westcot, D. W. (1985). Water Quality for Agriculture. Rome: FAO Irrigation and Drainage Paper. 
Ayers, R. S., \& Westcot, D. W. (1994). Water Quality for Agriculture. Rome: FAO Irrigation and Drainage Paper.

Bricker, O. P., \& Jones, B. F. (1995). Main Factors Affecting the Composition of Natural Waters (pp. 1-5). Boca Raton, FL: CRC Press.

Bu, H., Tan, X., Li, S., \& Zhang, Q. (2010). Temporal and Spatial Variations of Water Quality in the Jinshui River of the South Qinling Mts., China. Ecotoxicology and Environmental Safety, 73, 907-913. https://doi.org/10.1016/j.ecoenv.2009.11.007

Carpenter, S. R., Caraco, N. F., Correll, D. L., Howarth, R. W., Sharpley, A. N., \& Smith, V. H. (1998). Nonpoint Pollution of Surface Waters with Phosphorus and Nitrogen. Ecological Applications, 8, 559-568. https://doi.org/10.1890/1051-0761(1998)008[0559:NPOSWW]2.0.CO;2

Choudhary, P., Dagankar, A., \& Praveen, S. (2007). Physiochemical Analysis of Groundwater for Evaluation of Drinking Water Quality at Dhar, M.P. National Environmental and Pollution Technology, 6, 109-112.

Dang, T., Tsujimura, M., Le, V., Kawachi, A., \& Thu, D. (2014). Chemical Characteristics of Surface Water and Groundwater in Coastal Watershed, Mekong Delta, Vietnam. Procedia Environmental Sciences, 20, 712-721. https://doi.org/10.1016/j.proenv.2014.03.085

Datta, D. K., \& Subramanian, V. (1997). Nature of Solute Loads in the Rivers of the Bengal Drainage Basin, Bangladesh. Journal of Hydrology, 198, 196-208. https://doi.org/10.1016/S0022-1694(96)03294-5

DoE (1997). The Environment Conservation Rules 1997 (pp. 1324-1327). Dhaka: Ministry of Environment and Forest.

Doneen, L. D. (1964). Notes on Water Quality in Agriculture. Davis: Department of Water Science and Engineering, University of California.

Durfer, C. M., \& Backer, E. (1964). Public Water Supplies of the Three Largest Cities in the US (p. 364). US Geological Survey, Water Supply, Paper No. 1812.

Eaton, F. M. (1942). Toxicity and Accumulation of Chloride and Sulfate Salts in Plants. Journal of Agricultural Research, 64, 357-399.

Eaton, F. M. (1950). Significance of Carbonates in Irrigation Waters. Soil Science, 69, 123-134. https://doi.org/10.1097/00010694-195002000-00004

FAO (2011). Irrigation in Southern and Eastern Asia in Figures. Rome.

Gupta, P. K. (2005). Methods in Environmental Analysis: Water, Soil and Air (pp. 1-127). Jodhpur: Agrobios.

Haritash, A. K., Kaushik, C. P., Kaushik, A., Kansal, A., \& Yadav, A. K. (2008). Suitability Assessment of Groundwater for Drinking, Irrigation and Industrial Use in Some North Indian Villages. Environmental Monitoring and Assessment, 145, 397-406. https://doi.org/10.1007/s10661-007-0048-x

Hasan, K. F., Khaleque, M., Shahjahan, M., \& Haque, M. A. (2007). Water Quality for Irrigation, Emphasis on Arsenic Contamination in Agriculture, 2004-2007.

Hem, J. D. (1970). Study and Interpretation of the Chemical Characteristics of Natural Water(2nd ed., p. 363). US Geological Survey, WSP 1473, Washington DC.

Hoekstra, A. Y., \& Mekonnen, M. M. (2012). The Water Footprint of Humanity. Proceedings of the National Academy of Sciences of the United States of America, 109, 3232-3237. https://doi.org/10.1073/pnas.1109936109

Islam, M. M., Azad, A. K., Ara, M. H., Rahman, M., Hassan, N., Swarnokar, S. C., \& Rabeya, I. (2016). Environmental Study on a Coastal River of Bangladesh with Reference 
to Irrigation Water Quality Assessment: A Case Study on Shailmari River, Khulna. Journal of Geoscience and Environmental Protection, 4, 41-64. https://doi.org/10.4236/gep.2016.410003

Jarvie, H. P., Whitton, B. A., \& Neal, C. (1998). Nitrogen and Phosphorus in East Coast British Rivers: Speciation, Sources and Biological Significance. Science of the Total Environment, 210, 79-109. https://doi.org/10.1016/S0048-9697(98)00109-0

Kelley, W. P. (1963). Use of Saline Irrigation Water. Soil Science, 95, 385-391. https://doi.org/10.1097/00010694-196306000-00003

Khalil, A. A., \& Arther, V. (2010). Irrigation Water Quality Guidelines. Reclaimed Water Project. Jordan Valley Authority and German Technical Cooperation.

Li, S., \& Zhang, Q. (2009). Geochemistry of the Upper Han River Basin, Chapter 2: Seasonal Variations in Major Ion Compositions and Contribution of Precipitation Chemistry to the Dissolved Load. Journal of Hazardous Materials, 170, 605-611. https://doi.org/10.1016/j.jhazmat.2009.05.022

Mahmud, R., Nauto, I., \& Ranjit, S. (2007). Assessment of Irrigation Water Quality by Using Principal Component Analysis in an Arsenic Affected Area of Bangladesh. Journal of Soil Nature, 1, 8-17.

Mass, E. V. (1990). Crop Salt Tolerance. In K. Tanji (ed.), Agricultural Salinity Assessment and Management (pp. 262-304). ASCE Manuals \& Reports on Engineering Practice No. 71, ASCE.

Meybeck, M., Kimstach, V., \& Helmer, R. (1992). Water Quality Assessment: A Guide to the Use of Biota, Sediments and Water in Environmental Monitoring (pp. 19-50). London: Chapman and Hall.

Mitra, B. K., Sasaki, C., Enari, K., Matsuyama, M., \& Pongpattanasiri, S. (2007). Ground Water Quality in Sand Dune Area of Northwest Honshu Island in Japan. Journal of Agronomuy, 6, 81-87. https://doi.org/10.3923/ja.2007.81.87

Natarajan, S. K., Ganapathy, M., Nagarajan, R., \& Somasundaram, S. (2005). Screening of Rice Accessions for Yield and Yield Attributes Contributing to Salinity Tolerance in Coastal Saline Soils of Tamil Nadu, India. Asian Journal of Plant Sciences, 4, 435-437. https://doi.org/10.3923/ajps.2005.435.437

Paliwal, K. V. (1972). Irrigation with Saline Water (p. 198). I.A.R.I. Monogram No. 2 (New Series), New Delhi.

Paliwal, K. V., \& Singh, S. (1967). Effect of Gypsum Application on the Quality of Irrigation Waters. Madras Agricultural Journal, 59, 646-647.

Qayyum, M. A. (1970). Tubewell Water Quality in Relation to Crop and Soil Management in SCARP-I. Bhalwal: Pakistan Water and Power Development Authority.

Rahman, M., Das, R., Hassan, N., \& Roy, K. (2014). Environmental Study on Water Quality of Mayur River with Reference to Suitability for Irrigation. International Journal of Environmental Sciences, 4, 1150-1167.

Ramesh, R., \& Anbu, M. (1996). Chemical Methods for Environmental Analysis: Water and Sediment. London: Macmillan Publishers.

Richards, L. A. (1954). Diagnosis and Improvement of Saline and Alkali Soils. US Salinity Laboratory Staff, Washington DC: US Department of Agriculture.

https://doi.org/10.1097/00010694-195408000-00012

Roy, S., \& Hassan, K. M. (2016). Scenario of Water Pollution by Retting of Jute and Its Impact on Aquatic Lives. In Proceedings of the 3rd International Conference on Civil Engineering for Sustainable Development (pp. 164-169). Khulna, Bangladesh: KUET.

Sawyer, C. N., \& McCarty, P. L. (1967). Chemistry for Sanitary Engineers. New York: 
McGraw-Hill.

Shahid, S., Chen, X., \& Hazarika, M. K. (2006). Evaluation of Groundwater Quality for Irrigation in Bangladesh Using Geographic Information System. Journal of Hydrology and Hydromechanics, 54, 3-14.

Shrestha, S., \& Kazama, F. (2007). Assessment of Surface Water Quality Using Multivariate Statistical Techniques: A Case Study of the Fuji River Basin, Japan. Environmental Modelling \& Software, 22, 464-475. https://doi.org/10.1016/j.envsoft.2006.02.001

Singh, K. P., Malik, A., Mohan, D., \& Sinha, S. (2004). Multivariate Statistical Techniques for the Evaluation of Spatial and Temporal Variations in Water Quality of Gomti River (India)-A Case Study. Water Research, 38, 3980-3992.

https://doi.org/10.1016/j.watres.2004.06.011

Sundaray, S. K., Nayak, B. B., \& Bhatta, D. (2009). Environmental Studies on River Water Quality with Reference to Suitability for Agricultural Purposes: Mahanadi River Estuarine System, India-A Case Study. Environmental Monitoring and Assessment, 155, 227-243. https://doi.org/10.1007/s10661-008-0431-2

Tiwari, T. N., \& Manzoor, A. (1988). River Pollution in Kathmandu Valley (Nepal) Suitability of River Water for Irrigation. Indian Journal of Environmental Protection, 8, 269-274.

Tsado, P. A., Lawal, B. A., Igwe, C. A., Eze, P. C., \& Saidu, O. I. (2014). Assessment of the Suitability of Water Quality for Irrigation in Minna, Niger State. International Journal of Resource Agriculture and Forestry, 1, 44-49.

Varol, M., Gokot, B., Bekleyen, A., \& Şen, B. (2012). Spatial and Temporal Variations in Surface Water Quality of the Dam Reservoirs in the Tigris River Basin, Turkey. Catena, 92, 11-21. https://doi.org/10.1016/j.catena.2011.11.013

Vyas, A., \& Jethoo, A. S. (2015). Diversification in Measurement Methods for Determination of Irrigation Water Quality Parameters. Aquatic Procedia, 4, 1220-1226. https://doi.org/10.1016/j.aqpro.2015.02.155

Wilcox, L. V. (1948). The Quality of Water for Irrigation Use. Tech Report.

Wilcox, L. V. (1955). Classification and Use of Irrigation Water. US Department of Agriculture-Circular.

Winpenny, J., Heinz, I., \& Koo-Oshima, S. (2010). The Wealth of Waste: The Economics of Wastewater Use in Agriculture. Rome: FAO Water Reports. 